\title{
Influence of Starch and Casein Administered Postruminally on Small Intestinal Sodium-Glucose Cotransport Activity and Expression
}

\author{
Kátia Cylene Guimaraes ${ }^{1}$, Sarah Rodrigues Hazelton ${ }^{2}$, James Clyde Matthews ${ }^{2}$, Kendall \\ Carl Swanson ${ }^{3}$, David Lee Harmon ${ }^{3} *$ and Antonio Ferriani Branco ${ }^{1}$ \\ ${ }^{1}$ Universidade Estadual de Maringá; Av. Colombo, 5790; 87020-990; Maringá - PR - Brasil. ${ }^{2}$ Department of \\ Animal Sciences; University of Kentucky; Lexington 40546-0215. ${ }^{3}$ Department of Animal and Poultry Science; \\ University of Guelph; Guelph; Ontario - Canada
}

\begin{abstract}
Twenty-four Holstein steer calves $(88 \pm 3 \mathrm{~kg})$ with abomasal catheters were randomly assigned within blocks to one

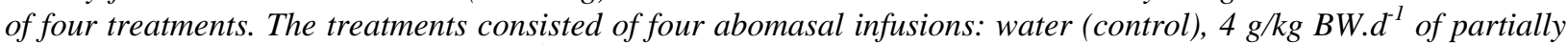

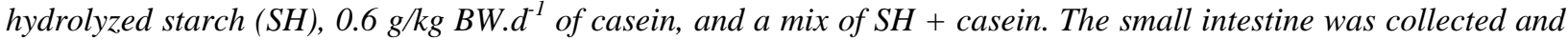
five equidistan, $1 \mathrm{~m}$ sites were identified (duodenum, jejunum 1, jejunum 2 jejunum 3 and ileum). Maltase specific activity in mucosal homogenate and brush border membrane vesicles, SGLT1 protein abundance, and sodiumdependent glucose uptake in brush border membrane vesicles did not differ between the calves receiving different abomasal infusion treatments. However, maltase specific activity in homogenates and brush border membrane vesicles increased four-fold from the duodenum to the first jejunal site before declining steadily towards the ileum ( $p=0.0145 p=0.0020$, respectively). The SGLT1 abundance differed by intestinal sampling site $(p=0.0162)$. These data indicated that cattle might not have the ability to alter the capacity for glucose uptake when challenged with different substrates and that the regulation of SGLT1 expression could differ between bovine and other species.
\end{abstract}

Key words: Cattle, glucose, maltase, sodium-dependent glucose co-transporter, starch

\section{INTRODUCTION}

Differences in the ruminal degradability and digestibility of dietary starch and protein influence not only the extent of microbial fermentation and protein synthesis in the rumen, but also the availability of nutrients to the post ruminal digestive tract. The majority of dietary starch is digested in the rumen, but the extent of ruminal digestion varies with animal species, grain processing and other dietary factors (Owens et al. 1986). For ruminants, glucose availability to the small intestine is highly dependent on diet.
Animals fed concentrate diets have increased glucose availability in the lumen of the small intestine compared with animals fed forage. Starch digestion in the small intestine is more energetically efficient than ruminal fermentation (Harmon and McLeod, 2001). However, any starch that escapes assimilation in the small intestine is subject to fermentation in the large intestine where efficiency is lowest. Therefore, it is critical that the capacity for small intestinal digestion not be exceeded.

It is thought that, in the small intestine, glucose is transported across the brush border membrane of

\footnotetext{
${ }^{*}$ Author for correspondence
} 
enterocytes by the $\mathrm{Na} /$ glucose cotransporter (SGLT1; Wright, 1993). In other mammalian species, the functional and structural adaptation in the digestive system are attributed mainly to characteristics of the diet. Shirazy-Beechey et al. (1991) demonstrated that in sheep the expression of intestinal SGLT1 is directly linked to the levels of luminal monosaccharides. However, no such evidence exists in cattle. Increasing small intestinal protein has increased starch digestion (Taniguchi et al., 1993; Richards et al. 2002) and pancreatic $\alpha$-amylase secretion (Richards et al., 2003) and expression (Swanson et al., 2002) in ruminants. Based on the strong influence protein (casein) has on intestinal physiology in ruminants it could be hypothesized that the luminal presence of protein (casein) could affect the intestinal expression of SGLT1. The objective of this study was to evaluate the interactions of intestinal $\alpha$ linked glucose and casein on glucose transporter activity along the length of the small intestine of the bovine.

\section{MATERIALS AND METHODS}

\section{Animal and abomasal infusion treatments}

The surgical procedures, diet, animal care and treatments were previously described (Swanson et al., 2002). Briefly, twenty-four Holstein steer calves $(88 \pm 3 \mathrm{~kg})$ with abomasal catheters were fed an alfalfa-based diet and randomly assigned within the block (week of infusion) to one of four treatments: water (control), $4 \mathrm{~g} / \mathrm{kg} \mathrm{BW} \cdot \mathrm{d}^{-1}$ of partially hydrolyzed starch (SH), $0.6 \mathrm{~g} / \mathrm{kg} \mathrm{BW} . \mathrm{d}^{-1}$ of casein and a mix of $\mathrm{SH}+$ casein. The infusion rate was $125 \mathrm{~mL} / \mathrm{h}$ for all treatments. The abomasal infusion periods were $10 \mathrm{~d}$.

\section{Tissue collection}

The animals were killed by the intravenous administration of pentobarbital sodium $(170 \mathrm{mg} / \mathrm{kg}$ BW, Sigma Chemical,USA). The small intestine was cut free of attached mesentery and looped around pegs attached to a $2 \mathrm{~m}$ measuring board. Using this scheme the total length could be quickly determined and five equidistant, $1 \mathrm{~m}$ sites were identified (duodenum, jejunum 1, jejunum 2 jejunum 3 and ileum) and cut free. The sections were flushed with ice-cold saline, divided in three equal lengths, everted, rinsed twice by immersion in ice-cold saline and placed in aluminum pouches. The pouches were identified, frozen in liquid $\mathrm{N}$ and stored at $-80^{\circ} \mathrm{C}$.

\section{Vesicle preparation and assays}

All the procedures were done on ice $\left(4^{\circ} \mathrm{C}\right)$ and brush border membrane vesicles (BBMV) were prepared according to Kessler et al. (1978) as modified by Shirazi-Beechey et al. (1991). The frozen tissue was placed in buffer $(100 \mathrm{mM}$ mannitol, $2 \mathrm{mM}$ HEPES adjusted to $\mathrm{pH} 7.1$ with Tris at $4^{\circ} \mathrm{C}$ ), thawed and then cut in small pieces. A vibration mixer (CHEMAP AG CH-8604, Volketswill, Switzerland) setting at 80 was used (2 $\mathrm{x} 1 \mathrm{~min}$ ) to release the cells from the basal lamina. The tissue was filtered through a Büchner funnel to obtain the original homogenate. Magnesium chloride was added to a $10 \mathrm{mM}$ final concentration, and the suspension was stirred for $20 \mathrm{~min}$. Brush border membrane vesicles were enriched by differential centrifugation (5 min at 3,000 $\mathrm{x} g$ and $30 \mathrm{~min}$ at $30,000 \mathrm{x} \mathrm{g})$. The pellet was resuspended in buffer (100 mM mannitol, $20 \mathrm{mM}$ HEPES adjusted to $\mathrm{pH} 7.5$ with Tris at $4^{\circ} \mathrm{C}$ ), homogenized by 10 strokes in a Potter-Elvehjem homogenizer and recentrifuged $(30,000 \mathrm{xg}, 30 \mathrm{~min})$. The final pellet was resuspended in buffer $(300 \mathrm{mM}$ mannitol, $0.1 \mathrm{mM} \mathrm{MgSO}_{4}, 20 \mathrm{mM}$ HEPES adjusted to $\mathrm{pH} 7.5$ with Tris at $4^{\circ} \mathrm{C}$ ) and stored in liquid nitrogen. Protein concentration of the homogenate and vesicles were determined with bovine serum albumin as the standard (Lowry et al., 1951). Maltase activity was assayed by the method of Turner and Moran (1982). The maltase specific activity was expressed as micromoles of product formed per minute of incubation per milligram of protein incubated. Enrichments in the brush border membrane preparation were the quotient of specific activity (maltase) in the BBM preparation and the initial homogenate.

\section{Assay of $\mathrm{Na}^{+}$- dependent glucose transport}

$\mathrm{Na}^{+}$- dependent glucose transport in the BBMV was measured at $37^{\circ} \mathrm{C}$ in the presence of either NaSCN or KSCN using the rapid filtration stop technique solution as described by Bauer et al. (2001). Uptake measurements were performed in triplicate. Sodium-dependent glucose uptake was the difference between $\mathrm{Na}^{+}$and $\mathrm{K}^{+}$incubations.

\section{Immunoblot}

Protein abundance of SGLT1, alkaline phosphatase and GLUT2 were determined in 
homogenates and BBMV by Western blotting and enrichments calculated as described previously (Rodriguez et al., 2004). Proteins (40 $\mu \mathrm{g} / \mathrm{lane})$ were separated in a $7.5 \%$ SDS PAGE, and electrotransferred to a $0.45-\mu \mathrm{m}$ nitrocellulose membrane (BioRad, USA). The membrane was then incubated with rabbit anti-rabbit SGLT1 (Alpha diagnostic, USA), calf anti-rabbit alkaline phosphatase, (Biodesign, Saco, Maine) or rabbit anti-rat glucose transporter 2, (Alpha diagnostic). The membranes were then incubated with a donkey anti-rabbit IgG horseradish peroxidase conjugated secondary antibody (Amershan Bioscience, USA). Immunoreactive products were visualized by chemiluminescence (Pierce, USA) and exposed to film (AmershamBiosciences, USA).

\section{Isolation of RNA and Northern Blot}

Total RNA was isolated from tissue samples using Trizol ® Reagent (Invitrogen life Technologies, USA), in a guanidinium thiocyanate/ phenol/chloroform extraction procedure (Chomczynski and Sacchi, 1987). The final pellet was resuspended in RNAse free water and stored at $-80^{\circ} \mathrm{C}$. The poly $(\mathrm{A})^{+}$-selected mRNA was extracted using the Polytract ${ }^{\circledR}$ mRNA isolation system (Promega, USA). Three micrograms of poly $(\mathrm{A})^{+}$were size-separated by electrophoresis using a $1 \%$ agarose, $20 \mathrm{mmol} / \mathrm{L}$ formaldehyde gel, transferred by downward capillary action to a 0.45 $\mu \mathrm{m}$ nylon membrane, air-dried and covalently cross-linked by UV light. The samples were then hybridized with ${ }^{32} \mathrm{P}$-labeled rabbit SGLT1 cDNA (Hirayama et al., 1996) in a solution containing $1 \%$ bovine serum albumin, $243 \mathrm{mmol} / \mathrm{L}$ sodium dodecyl sulfate (SDS), $500 \mathrm{mmol} / \mathrm{L} \mathrm{Na}_{2} \mathrm{HPO}_{4}(\mathrm{pH}$ 7.2) and $1 \mathrm{mmol} / \mathrm{L}$ EDTA for $15 \mathrm{~h}$ at $55^{\circ} \mathrm{C}$. After hybridization, the blots were washed $3 \times 15 \mathrm{~min}$ at $55^{\circ} \mathrm{C}, 57^{\circ} \mathrm{C}$ and $59^{\circ} \mathrm{C}$ respectively. The washing solution contained: $40 \mathrm{mmol} / \mathrm{L} \mathrm{Na}_{2} \mathrm{PO}_{4}(\mathrm{pH} \mathrm{7.2})$, $3.5 \mathrm{mmol} / \mathrm{L}$ SDS and $1 \mathrm{mmol} / \mathrm{L}$ EDTA. Blots then were exposed to autoradiographic film overnight (AmershamBiosciences, USA).

Densitometry and molecular size determination The autoradiographic film from immunoblot and northern blot was scanned (HP DeskScan II, USA) and the UN-SCANIT software program (Silk Scientific, USA) was used to determine the intensities of the band. Apparent sizes were calculated by regression of the distance migrated against the molecular weight or size markers 10Kda protein ladder from Invitrogen, USA and and $0.2-10 \mathrm{~Kb}$ RNA ladder from Sigma Chemical, USA, respectively.

\section{Statistical Analysis}

Data were analyzed as a split-plot design using the GLM procedures of SAS (1988). The whole plot included block (group of 4 calves) and treatment effects (starch, casein and the starch $\mathrm{x}$ casein interaction). The block with in treatment term was used as the whole-plot error term. The split-plot sources of variation included intestinal site and the interactions of starch and casein with intestinal site. Differences were considered statistically significant when $\mathrm{P} \leq 0.05$.

\section{RESULTS}

Regarding the BBMV preparation, on average, the enrichment for SGLT1 and alkaline phosphatase in BBMV were five times higher than the enrichment for GLUT2 (Table 1). The higher presence of SGLT1 compared with GLUT2 in BBMV showed that the vesicle preparations contained brush border membranes with a low contamination of basolateral membranes. The level of alkaline phosphatase enrichment also indicated that vesicles were obtained from apical membranes where the SGLT1 transporter was located. Both results indicated a consistent preparation of membranes independent of site.

The maltase specific activity in vesicles and homogenates did not differ by the treatment (Table 3 ). On the other hand, maltase specific activity in homogenates (Table 2) increased four-fold from the duodenum to the first jejunal site before declining steadily towards the ileum $(p=0.0145)$. For the vesicles, maltase specific activity also increased four-fold from the duodenum to the first part of jejunum, but there was a smaller decrease from the beginning to the middle of jejunum, and then it decreased toward the ileum $(\mathrm{p}=0.0020)$. Maltase enrichment was not affected by small intestinal sampling site but tended to be lower at the first jejunal site $(\mathrm{p}=0.0935)$.

The sodium-dependent glucose uptake differed by the intestinal sampling site $(\mathrm{p}<0.0001)$. Sodiumdependent glucose transport was maximal in the duodenum and decreased from the duodenum to the middle of the jejunum and then decreased tenfold from the middle of jejunum to the ileum 
(Table 2). However, there was no effect of the treatment on sodium dependent glucose uptake (Table 3).

Table 1 - SGLT1, GLUT2 and Alkaline phosphatase enrichments for brush border membranes.

\begin{tabular}{lcc}
\hline Protein & Average Enrichment & SEM \\
\hline SGLT11 & 4.91 & 1.85 \\
GLUT22 & 1.14 & 0.18 \\
Alkaline Phosphatase & 5.57 & 1.76 \\
\hline $\mathrm{n}=4$ & &
\end{tabular}

${ }^{2} \mathrm{n}=8$

Table 2 - Maltase specific activity (MSA) in vesicle and homogenate, SGLT1 abundance and Na-dependent glucose uptake along the small intestine of calves infused with water, HS, casein and HS + casein.

\begin{tabular}{|c|c|c|c|c|c|c|c|}
\hline \multicolumn{7}{|c|}{ Small Intestinal Site } & \multirow{2}{*}{$\frac{\text { Effect }}{\text { Site }}$} \\
\hline & Duodenum & Jejunum 1 & Jejunum 2 & Jejunum 3 & Ileum & SEM $^{1}$ & \\
\hline Homogenate $\mathrm{MSA}^{2}$ & 0.028 & 0.131 & 0.074 & 0.067 & 0.042 & 0.013 & 0.0171 \\
\hline Vesicle MSA & 0.081 & 0.323 & 0.319 & 0.264 & 0.155 & 0.034 & 0.0008 \\
\hline Enrichment $^{3}$ & 7.6 & 3.42 & 6.00 & 6.10 & 6.37 & 0.582 & 0.0935 \\
\hline SGLT1 Abundance & 1.62 & 2.08 & 2.57 & 1.95 & 1.00 & 0.218 & 0.0162 \\
\hline $\begin{array}{l}\text { Na-dependent } \\
\text { glucose uptake }\end{array}$ & 69.29 & 39.12 & 23.71 & 2.28 & 2.82 & 3.707 & $<0.0001$ \\
\hline
\end{tabular}

${ }^{1}$ Standard error of mean, $\mathrm{n}=24$.

${ }^{2} \mu \mathrm{mol}$ of end product $\mathrm{x}$ mg of protein incubated ${ }^{-1} \mathrm{x}$ min of incubation ${ }^{-1}$

${ }^{3}$ vesicle/homogenate

${ }^{4}$ pmol.mg ${ }^{-1} \mathrm{X} \mathrm{S}^{-1}$

Immunoblot analysis for SGLT1 indicated a protein of $79.89 \pm 10.00 \mathrm{kDa}$ (Fig. 1). The SGLT1 abundance differed by intestinal sampling site $(p=0.0162)$. It increased from the duodenum to the middle of jejunum and then decreased (2.5 fold) toward the ileum. Nevertheless, SGLT1 abundance did not differ between treatments (Table 3).

Northern blot analysis confirmed the presence of SGLT1 mRNA in all sections of the small intestine (Table 4). The size of the band for SGLT1 mRNA was $4.0 \mathrm{~kb}$ in all treatments.

\section{DISCUSSION}

There is considerable evidence that nutrient transporters in the small intestine are regulated by diet. For example, diets with high amounts of carbohydrate are able to increase glucose transport in the small intestine of rats (Miyamoto et al., 1993). In addition, there is evidence that the abundance and the activity of SGLT1 are regulated by the dietary carbohydrate for non-ruminants (Ferraris et al., 1989) and ruminants (ShiraziBeechey et al., 1991; Lescale-Matys et al., 1993). The apparent lack of an adaptive response may question the role of SGLT1 in carbohydrate assimilation in cattle.

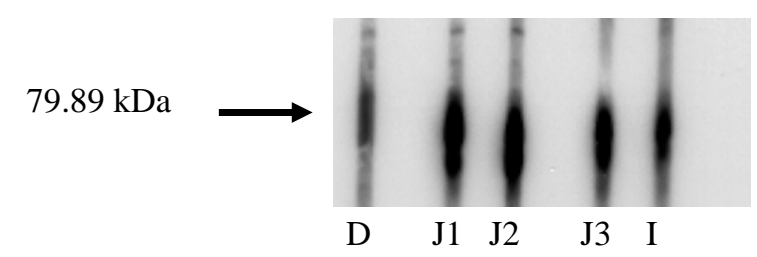

Figure 1 - Representative immunoblot indicating the SGLT1 presence along the small intestine of calves. D=Duodenum; J1=Proximal jejunum; J2= Middle jejunum; J3= Distal jejunum and $\mathrm{I}=\mathrm{Ileum}$ 
Table 3 - Maltase specific activity (MSA), SGLT1 abundance and Na-dependent glucose uptake in calves receiving abomasal infusion of water (control), HS, casein, or HS +casein.

\begin{tabular}{|c|c|c|c|c|c|c|c|c|}
\hline \multicolumn{6}{|c|}{ Treatments } & \multicolumn{3}{|c|}{ Effect } \\
\hline & Control & HS & Casein & $\begin{array}{c}\text { HS x } \\
\text { Casein }\end{array}$ & SEM1 & Starch & Casein & $\begin{array}{l}\text { HS } \quad{ }^{x} \\
\text { Casein }\end{array}$ \\
\hline Homogenate MSA2 & 0.047 & 0.091 & 0.059 & 0.067 & 0.013 & 0.3238 & 0.3376 & 0.9776 \\
\hline Vesicle MSA & 0.140 & 0.250 & 0.250 & 0.274 & 0.034 & 0.8202 & 0.8096 & 0.6403 \\
\hline Enrichment 3 & 6.07 & 5.25 & 6.72 & 5.57 & 0.582 & 0.2656 & 0.4446 & 0.7252 \\
\hline SGLT1 Abundance & 2.16 & 1.85 & 1.70 & 1.65 & 0.218 & 0.2350 & 0.8292 & 0.1375 \\
\hline $\begin{array}{l}\text { Na-dependent glucose } \\
\text { uptake } 4\end{array}$ & 17.39 & 32.89 & 28.33 & 31.16 & 3.707 & 0.5665 & 0.6259 & 0.9315 \\
\hline
\end{tabular}

Table 4 - SGLT1 mRNA abundance (arbitrary units) along the small intestine in calves receiving abomasal infusion of water (control), HS, casein, or HS + casein $^{\text {a }}$

\begin{tabular}{lcc}
\hline Small Intestine & SGLT1 mRNA Abundance & Standard Error \\
Site & & 0.29 \\
\hline Duodenal & 0,08 & 0.09 \\
Jejunum 1 & 0.22 & 0.11 \\
Jejunum 2 & 0.41 & 0.16 \\
Jejunum 3 & 0.59 & 0.07 \\
Ileum & 0.19 &
\end{tabular}

The objective of this study was to evaluate the interactions of intestinal $\alpha$-linked glucose and casein on SGLT1 expression, abundance and transporter activity along the length of the small intestine of the bovine. It was hypothesized that since casein infusion increased the intestinal starch disappearance (Richards et al., 2002) and increased the pancreatic $\alpha$-amylase secretion (Richards et al., 2003) it would also increase the glucose transport from the small intestine. Mabjeesh et al. (2003) reported that in sheep casein increased SGLT1 activity in the midjejunum. However, unlike other work (ShiraziBeechey et al., 1991;Shirazi-Beechey et al., 1989) showing adaptive responses to increased intestinal glucose in lambs, there was not an adaptive response to the increased intestinal starch (Bauer et al., 2001) or starch and glucose (Rodriguez et al., 2004) in cattle. This lack of increase in activity of SGLT1 was also seen in the present work in response to increased intestinal starch and casein. Swanson et al. (2002) reported changes in the pancreatic amylase expression and pancreatic weight, indicating that abomasal infusion treatment was eliciting physiological effects on the calves.

Brush border membrane vesicles (BBMV) are commonly used to study the nutrient transport, enzyme activity, and identify proteins present in the brush border membrane. The uptake studies were done using brush border membranes from the small intestine. To determine the success of the BBMV preparation, the maltase enrichment was determined. Results indicated that maltase enrichment was the same for all the samples, regardless of treatment and site. Thus, the glucose transport results probably reflected the effect of treatment and site on the transport and not differences in the vesicle preparation.

The presence of HS and/or protein did not change the maltase activity (Table 3) over the small intestine of calves. It confirmed the hypotheses proposed by Harmon (1992) that the intestinal mucosa has a limited ability to change the disaccharidase activity in response to diet. However, present results were different from those observed in steers (Bauer et al., 2001; Rodriguez 
et al., 2004) where higher maltase activities were obtained in animals abomasally infused with HS.

The values for sodium-dependent glucose uptake ranged from $69.29 \mathrm{pmol} \cdot \mathrm{mg}^{-1} \cdot \mathrm{s}^{-1}$ for duodenal samples to $2.28 \mathrm{pmol} . \mathrm{mg}^{-1} \cdot \mathrm{s}^{-1}$ for the samples from the ileum. These values were similar to those $\left(36.84-2.0 \mathrm{pmol} . \mathrm{mg}^{-1} \cdot \mathrm{s}^{-1}\right)$ found by Rodriguez et al. (2004) but lower than those (204 \pm 24 pmol.mg $\left.{ }^{1} . \mathrm{s}^{-1}\right)$ reported by Bauer et al. (2001) in cattle and those $\left(347 \pm 130\right.$ pmol. $\left.\mathrm{mg}^{-1} \cdot \mathrm{s}^{-1}\right)$ reported by (Shirazy-Beechey et al., 1991) in the duodenum of suckling lambs. However, the present results were higher than the ones reported by Shirazy-Beechey et al.. (1991) in lambs (12 -wk-old) and adult sheep $\left(6.1 \pm 0.7\right.$ and $4.0 \pm 1.5$ pmol. $\mathrm{mg}^{-1} \cdot \mathrm{s}^{-1}$, respectively)

Another important aspect to be considered is the SGLT1 mRNA presence and distribution along the small intestine. The performed northern blotting analysis evidenced the presence of SGLT1 mRNA in all the small intestine sections evaluated. The transcripts consisted of a band of approximately 4.0- $\mathrm{kb}$ and the band was similar for all the treatments. In accordance with these results, Wood et al. (2000) evidenced a major band of approximately $4.4-\mathrm{kb}$ for the pre-ruminant calf intestine and Zhao et al. (1998) reported the presence of SGLT1 mRNA in many regions of lactating bovine intestinal tract, including rumen, omasum, duodenum, jejunum, ileum and cecum. Although the northern blotting analysis was performed for only one block (6) of the animals, it was observed that SGLT1 expression increased from the duodenum to the middle of the jejunum. The amount of SGLT1 mRNA then decreased from the middle of the jejunum to the ileum. Kojima et al. (1999) also showed an increased expression of SGLT1 mRNA in the initial portion of jejunum in rats. However, Barfull et al. (2002) did not find local differences in SGLT1 mRNA expression along the intestine of chickens. As the presence of SGLT1 mRNA alone did not establish the presence of the protein; western blotting and uptake studies were done to confirm that SGLT1 had a functional role along the small intestine.

Immunoblot analysis revealed an $80 \mathrm{kDa}$ band for SGLT1 in all the segments of the small intestine (Fig. 1). The observed molecular weight of SGLT1 in this experiment was consistent with the molecular weight of SGLT1 in the mammalian species, which was between 60 to $82 \mathrm{kDa}$ (Peerce and Wright, 1984; Koepsell, 1986).
Concerning SGLT1 protein expression, a higher abundance of SGLT1 protein in the proximal and middle jejunum, independent of treatment (Table 3) was found. This observation was in contrast with the previous study which indicated a linear increase in the protein abundance proceeding distally along the small intestine of steers (Rodriguez et al., 2004). As reported by Dyer et al. (1997), changes in SGLT1 abundance along the small intestine of sheep could indicate variation in the sodium-dependent glucose transport capacity over the segments. However, there was no change in SGLT1 activity of brush border membrane vesicles of cattle (Rodriguez et al., 2004).

The SGLT1 transport activity analysis showed no differences in glucose transport within distinct intestine locations. The highest glucose uptake occurred in the duodenum and decreased along the small intestine. This pattern of glucose uptake was different from sheep (White et al., 1971), steers (Krehbiel et al. 1996; Bauer, 1996) and dairy cows (Zhao et al., 1998) where the highest glucose activity occurred in the jejunum. This could be because of the age of the calves as the calves were approximately 3 months old. Dyer et al. (1997) studied the influence of age on sodium-dependent glucose transporter activity and SGLT1 abundance in the lambs and observed a decline in the transport and SGLT1 abundance with increasing age. Khan et al. (2000) evaluated the age effect in rat SGLT1 expression over three stages of development (suckling, weaning and mature) and observed a higher abundance of the protein in the weaning animals indicating that age and development could influence the glucose transport. Present results showed no correlation among SGLT1 transport activity and protein presence along the small intestine of the experienced animals. This could be due to: the SGLT1 molecules in the membrane were not functional or were being regulated by an unknown mechanism; the involvement of other sodium dependent proteins, or the presence of other processes that limited the intestinal carbohydrate assimilation along the small intestine. Although, this behavior was different from other species such as sheep (Shirary-Beechey et al, 1991; Dyer et al 1997), rats (Miyamoto et al., 1993) and humans (Dyer et al., 1997), it agreed with the previous study in the steers, which indicated that SGLT1 abundance did not correlate with Na-dependent glucose transport (Rodriguez et al., 2004). Wright and Loo (2000) suggested that SGLT1 was able to transport water 
as well as glucose and sodium, which might indicate a possible role of SGLT1 in the water transport in the distal small intestine. Aschenbach et al. (2000) reported that SGLT1 was present in the rumen epithelial tissue, a tissue with little or no access to free glucose, and it was functional in vitro with tissue from fasted sheep (Gabel and Aschenbach, 2002). These results suggest that the role of SGLT1 could be quite different in the ruminant as compared to the non-ruminant.

In summary, the present work provided information about the glucose transporter activity and expression along the small intestine of the calves receiving starch and casein infusions. It suggested that increased small intestinal flow of starch and/or casein did not affect the small intestinal sodium-dependent glucose uptake, SGLT1 protein abundance and maltase activity. However, small intestinal sampling site did influence the maltase activity, sodium-dependent glucose uptake, and SGLT1 abundance. Results also indicated that sodium-dependent glucose transport activity, as related to small intestinal sampling site, was not directly correlated with SGLT1 abundance.

\section{ACKNOWLEDGEMENTS}

We thank Ernest M. Wright from the University of California, Los Angeles (CA) for the SGLT1 cDNA probe.

\section{REFERENCES}

Aschenbach, J.R., Wehning, H., Kurze, M., Schaberg, E., Nieper, H., Burckhardt, G., and Gabel, G., (2000), Functional and molecular biological evidence of SGLT-1 in the ruminal epithelium of sheep. Am. J. Physiol Gastrointest. Liver Physiol., 279, G20-G27.

Barfull, A., Garriga C., Tauler A., and Planas J. M. (2002), Regulation of SGLT1 expression in reponse to $\mathrm{Na}^{+}$intake. Am. J. Physiol. Regulatory Integrative Comp. Physiol., 282, R738-R743.

Bauer, M. L. (1996), Nutritional regulation of small intestinal glucose absorption in ruminants. $\mathrm{PhD}$ Thesis, University of Kentucky, Lexington, KY, USA.

Bauer, M. L., Harmon D.L., Bohnert D.W., Branco A.F., and Huntington G.B. (2001), Influence of $\alpha$ linked glucose on sodium-glucose cotransport activity along the small intestine in cattle. J. Anim. Sci., 79, 1917-1924.
Cromczynski, P. and Sacchi N. (1987), Single-step method of RNA isolation by acid guanidinium thiocyanate-phenol-chloroform extraction. Anal. Biochem., 162, 156-159.

Dyer, J., Barker P.J., and Shirazi-Beechey S.P. (1997), Nutrient regulation of the intestinal $\mathrm{Na}^{+} /$glucose cotransporter (SGLT1) gene expression. Biochem. Biophys. Res. Commun., 230, 624-629.

Dyer, J., Hosie K.B., Shirazi-Beechey S.P. (1997), Nutrient regulation of human intestinal sugar transporter (SGLT1) expression. Gut., 41, 56-59.

Ferraris, R. P., Lee P.P., and Diamond J.M. (1989), Origin of regional and species differences in intestinal glucose uptake. Am. J. Physiol., 257, G689G697.

Gabel, G. and Aschenbach, J.R., (2002), Influence of food deprivation on the transport of 3-O-methylalpha-D-glucose across the isolated ruminal epithelium of sheep. J. Anim Sci., 80, 2740-2746.

Harmon, D. L. (1992), Dietary influences on carbohydrases and small intestinal starch hydrolysis capacity in ruminants. J. Nutr., 122, 203-210.

Harmon, D. L. and McLeod K.R. (2001), Glucose uptake and regulation by intestinal tissues: implications and whole-body energetics. J. Anim. Sci., 79 (E. Suppl.), E59-E72.

Hirayama, B.A., Lostao, M.P., Panayotova-Heiermann, M., Loo, D.D., Turk, E., and Wright, E.M., 1996. Kinetic and specificity differences between rat, human, and rabbit $\mathrm{Na+-}$ glucose cotransporters (SGLT-1). Am. J. Physiol 270, G919-G926.

Khan, J. M., Wingertzahn M.A., Teichberg S., Vancurova I., Harper R.G., and Wapnir R.A. (2000), Development of the intestinal SGLT1 transporter in Rats. Mol. Gen. Met., 69, 233-239.

Kessler, M., Acuto O., Storelli C., Murer H., Muller M., and Semenza G. (1978), A modified procedure for the rapid preparation of efficiently transporting vesicles from small intestinal brush border membranes. Biochim. Biophys. Acta., 506, 136-154.

Krehbiel, C. R., Britton R.A., Harmon D.L., Peters J.P., Stock R.A., and Grotjan H.E. (1996), Effects of varying levels of duodenal or midjejunal glucose and 2-deoxyglucose infusion on small intestinal disappearance and net portal glucose flux in steers. $J$. Anim. Sci., 74, 693-700.

Kreikemeier, K.K. and Harmon, D.L., (1995), Abomasal glucose, maize starch and maize dextrin infusions in cattle: small intestinal disappearance, net portal glucose flux and ileal oligosaccharide flow. $\mathrm{Br}$. J. Nutr., 73, 763-772.

Kreikemeier, K.K., Harmon, D.L., Brandt, R.T., Jr., Avery, T.B., and Johnson, D.E., (1991), Small intestinal starch digestion in steers: effect of various levels of abomasal glucose, corn starch and corn dextrin infusion on small intestinal disappearance and net glucose absorption. J. Anim. Sci., 69, 328-338. 
Koepsell, H. (1986), Methodological aspects of purification and reconstitution of transport proteins from mammalian plasma membranes. Rev. Physiol. Biochem. Pharmac., 104, 65-137.

Kojima, T., Nishimura M., Yajima T., Kuwata T., Y. Suzuki Y., Goda T., Takase S. and Harada E. (1999), Development changes in the regional $\mathrm{Na}+$ /glucose transporter mRNA along the small intestine of suckling rats. Comp. Biochem. Physiol. Part B: Biochem. Mol. Biol., 122, 89-95.

Lescale-Matys, L., Dyer J., Scott D., Freeman T.C., Wright E.M., and Shirazi-Beechey S.P. (1993), Regulation of the ovine intestinal $\mathrm{Na}^{+} /$glucose cotransporter (SGLT1) is dissociated from mRNA abundance. Biochem. J., 291, 435-440.

Lowry, O. H., Rosenburgh N.J., Farr A.L., and Randall R.J. (1951), Protein measurement with the folin phenol reagent. J. Biol. Chem., 193, 265-275.

Mabjeesh, S.J., Guy, D., and Sklan, D., (2003), $\mathrm{Na}$ /glucose co-transporter abundance and activity in the small intestine of lambs: enhancement by abomasal infusion of casein. Br. J. Nutr,. 89, 573580.

Miyamoto, K., Hase K., Takagi T., Fuji T., Taketani Y., Minami H., Oka T., and Nakobou Y. (1993). Differential responses of intestinal glucose transporter mRNA transcripts to level of dietary sugars. Biochem. J., 295, 211-215.

Owens, F. N., Zinn R.A., and Kim Y.K. (1986), Limits to starch digestion in the ruminant small intestine. $J$. Anim. Sci., 63, 1634-1648.

Peerce, B. E., and Wright E.M. (1984), Conformational changes in the intestinal brush border membrane $\mathrm{Na}+$ /glucose co-transporter labeled with fluorescein isothiocyanate. Proc. Nat. Acad. Sci., 81, 2223-2226.

Richards, C.J., Branco, A.F., Bohnert, D.W., Huntington, G.B., Macari, M., and Harmon, D.L. (2002), Intestinal starch disappearance increased in steers abomasally infused with starch and protein. $J$. Anim Sci., 80, 3361-3368.

Richards, C.J., Swanson, K.C., Paton, S.J., Harmon, D.L., and Huntington, G.B. (2003), Pancreatic exocrine secretion in steers infused post-ruminally with casein and corn starch. J. Anim. Sci., 81, 10511056.

Rodriguez, S. M., Guimaraes, K.C., Matthews, J.C., McLeod, K.R., Baldwin, R.L. and Harmon, D.L. (2004), Influence of abomasal carbohydrates on small intestinal sodium-dependent glucose cotransporter activity and abundance in steers. J. Anim. Sci., 82, 3015-3023.

SAS. SAS language guide for personal computers (Release 6.03 Edition). (1988), Cary, NC, SAS Inst. Inc., USA.
Shirazi-Beechey, S.P., Kemp, R.B., Dyer, J., and Beechey, R.B. (1989), Changes in the functions of the intestinal brush border membrane during the development of the ruminant habit in lambs. Comp. Biochem. Physiol., 94B, 801-806.

Shirazi-Beechey, S. P., Hirayama B.A., Wang Y., Scott D., Smith M.W., and Wright E.M. (1991), Ontogenic development of lamb intestinal sodium-glucose cotransporter is regulated by diet. J. Physiol., 437, 699708.

Swanson, K.C., Matthews, J.C., Woods, C.A., and Harmon, D.L. 2002. Post-ruminal administration of partially hydrolyzed starch and casein influences pancreatic $\square$-amylase expression in calves. J. Nutr. 132, 376-381.

Taniguchi, K., Sunada, Y., Obitsu, T. (1993), Starch digestion in the small intestine of sheep sustained by intragastric infusion without protein supply. Anim. Feed Sci. Technol., 64, 892-895.

Turner, R. J. and Moran A. (1982), Heterogeneity of sodium-dependent D-glucose transport sites along the proximal tubule: evidence from vesicle studies. Am. J. Physiol., 242, F406-F414.

White, R.G., Williams V.J., and Morris R. J. (1971), Acute in vivo studies on glucose absorption from the small intestine of lambs, sheep and rats. Br. J. Nutr. 25, 57-76.

Wright, E. M. (1993), The intestinal $\mathrm{Na}^{+} /$glucose cotransporter. Annu. Rev. Physiol., 55, 575-589.

Wright, E. M. and Loo D.D. (2000), Coupling between $\mathrm{Na}^{+}$, sugar, and water transport across the intestine. Ann. N Y Acad. Sci., 915, 54-66.

Wood, I. S., Dyer J., Hofmann R.R., and ShiraziBeechey S.P. (2000), Expression of the $\mathrm{Na}^{+} /$glucose co-transporter (SGLT1) in the intestine of domestic and wild ruminants. Euro. J. Physiol., 441, 155-162.

Zhao, F. Q., Okine E.K., Cheeseman C.I., ShiraziBeechey S.P., and Kennely J.J. (1998), Glucose transporter gene expression in lactating bovine gastrointestinal tract. J. Anim. Sci., 76, 2921-2929.

Received: August 30, 2005; Revised: November 07, 2006; Accepted: May 22, 2007. 